\title{
REMOULDING OF THE BINARY OPPOSITIONS IN OSCAR WILDE'S LADY WINDERMERE'S FAN
}

\author{
Oscar Wilde'ın Lady Windermere'in Yelpazesi Eserinde \\ ikili Karşıtlıkların Yeniden Yapılandırılması
}

\section{Seçil ERKOÇ*}

\section{ABSTRACT}

Considered as a misfit in his own time, Oscar Wilde (1854-1900) has an idiosyncratic perspective that defies the traditional regulations and social norms of the Victorian era. Witnessing the gradual disintegration of the moral values and the hypocritical practices of the late Victorian society, Wilde develops a humorous attitude which enables the reader/audience to question the ambivalent gaps between "sharp" distinctions - such as good and bad, honest and corrupt, pure and fallen in his works. Rejecting the status of art as an instrument of moral education that aims to guide the society, Wilde refrains from applauding the long-established values of the Victorian upper and upper-middle classes. Instead, he tries to draw attention to the hidden layers of meaning that bring the hypocritical agenda of the Victorian morals to the surface. In this respect, it is to be argued that illustrating the grey areas between Lady Windermere who, as a devout wife, was about the cross the line between a "good" and a "bad" woman if it were not for the altruism of her mother, and Mrs Erlynne, who is the so-called 'bad' woman with an unknown past, Wilde's Lady Windermere's Fan (1892) illustrates the interchangeable points between either/or dualities. Therefore, this paper intends to analyse the remoulding of the strict Victorian binaries - which have long been constructed in accordance with the hypocritical premises of the late $19^{\text {th }}$ century in England. In addition, although the main scope of this study is not concerned with applying a postmodern or feminist reading to the source text, in order to support Wilde's intention to problematize the constructed status of the binary oppositions, Julia Kristeva's (b. 1941) criticism against the patriarchal representation of women will also be touched upon.

Keywords: Oscar Wilde, Lady Windermere's Fan, Victorian era, dualism, social critique.

\footnotetext{
* Dr., İnönü University, Faculty of Arts and Sciences, Department of Western Languages and Literatures, Malatya/Turkey. E-mail: secilerkoc@hotmail.com. ORCID: 0000-0003-0934-331X. turniting This article was checked by Turnitin.
} 
öz

İçinde yaşadığı dönemin uyumsuz figürlerinden biri olarak kabul edilen Oscar Wilde (1850-1900), Viktorya çağının geleneksel düzen ve kurallarına meydan okuyan kendine özgü bir bakış açısına sahiptir. Geç Viktorya dönemine ait ahlaki değer yargılarının çözülüşüne ve ikiyüzlü uygulamalarına tanık olan Wilde, tiyatro eserlerinde okuyucunun/izleyicinin iyi ve kötü, dürüst ve yozlaşmış, masum ve günahkâr gibi "keskin" ayrımlar arasındaki muğlak alanları sorgulamasını sağlayan mizahi bir tavır geliştirir. Sanatın topluma rehberlik etmeyi amaçlayan ahlaki bir eğitim aracı olarak konumlanmasını reddeden Wilde, Viktorya dönemi üst ve üst-orta sınıfın kök salmış değerlerini alkışlamaktan imtina eder. Bunun yerine, Viktorya dönemi ahlakının riyakâr arka planını gün yüzüne çıkaracak olan üstü kapalı anlam katmanlarına dikkat çekmeye çalışır. Tüm bunlardan hareketle, Lady Windermere'in Yelpazesi (1892) eserinin, annesinin fedakârlığı olmasa "iyi” kadın/"kötü" kadın arasındaki çizgiyi aşmasına ramak kalan Lady Windermere ve bilinmeyen bir geçmişe sahip, sözde "kötü" kadın Bayan Erlynne arasındaki gri alanları betimleyerek, ya/ya da ikiliklerinin ötesindeki, birbiri ile değiştirilebilir olan noktaları örneklendirdiği tartışılacaktır. Dolayısıyla, bu makale 19. yüzyılın sonlarında ingiltere'de çözülmekte olan ahlaki değerler karşısında katı Viktorya dönemi ikiliklerinin nasıl yeniden yapılandırıldığını analiz etmeyi amaçlamaktadır. Ayrıca, her ne kadar bu çalışmanın ana kapsamı ilgili metne postmodern ya da feminist bir okuma uygulamakla ilgili olmasa da Wilde'ın ikili karşıtıkları sorgulayan tutumunu desteklemek adına, Julia Kristeva'nın (d. 1941) kadınların ataerkil temsiline yönelik eleştirisine de değinilmiştir.

Anahtar Sözcükler: Oscar Wilde, Lady Windermere'in Yelpazesi, Viktorya dönemi, ikilik, sosyal eleştiri.

\section{Introduction}

It is a difficult task to come up with a certain definition that describes Oscar Wilde (1854-1900), for his life was marked by his struggle against normativity and the conformist mindset of the Victorian England. He defied all the reductionist approaches that aimed at ascribing a single label to people because, according to him the formation of the self and the identity were always in a state of flux and change - feeding on various sources at a time. Thus, as an Irishman "who avowed he was a socialist, hinted that he was a homosexual, and patently was an antagonist of organized morals and religion," it is not surprising that Wilde challenged social, sexual, and moral conventions of his period (Ellmann, 1969: 3). On the other hand, "his position as a part-time outsider" enabled Wilde to have a broader vision of his society, and "with the detailed or semi-detached, perspective of his Celtic mind and imagination" he was able to see beyond the appearance - 
which in turn sharpened his analytical capacities (Raby, 1997: 158-59). In order to have a better understanding of such a versatile and colourful figure as Wilde, the scope of this paper will be limited to his position as a playwright for whom the theatre was one of the most important mediums to express his vision and to have an immediate contact with the audience.

Before going into detail, however, Wilde's life must be taken into account, for "it was itself a sensational drama" (Worth, 1987: 2). He was born in Dublin on 16 October 1854 as the son of a distinguished surgeon Sir William Wilde and Lady Jane Wilde, who, under the pseudonym "Speranza", campaigned and wrote for the Irish Home Rule. Following his graduation from Trinity College, Dublin Wilde moved to Oxford where his life began to change dramatically. Establishing his reputation as "wit, aesthete, and brilliant conversationalist," soon he came to be recognized by the high society of London (Worth, 1987: 2). In 1881 Wilde made a lecture tour to America where his first play Vera, or the Nihilist - published in 1880 - was produced in New York in 1882. In the following year he visited Paris where he met Sarah Bernhardt who would have acted in his play Salomé in London in 1892 "if the play had not been banned by the Lord Chamberlain under an archaic law prohibiting the representation on stage of biblical personages" (Worth, 1987: 3). His other early play The Duchess of Padua, written in 1883, was also produced in New York for a brief season in 1891 (Raby, 1988: 82). In 1884 he married Constance Lloyd and had two sons. Behind the façade of his 'ordinary' life, however, Wilde led a double life - brought to light through his friendship with Lord Alfred Douglas (1870-1945), which started in 1891 and urged Wilde to challenge the norms of the society. Charged with having an "unconventional" relationship with Douglas, Wilde was imprisoned in 1895 and was released two years later - only to leave for France where he stayed till his death in 1900.

Due to the failure of Vera on Broadway, which was also accompanied by several unsuccessful attempts, Wilde wrote nothing for the theatre for seven years. Nevertheless, in 1890 he began to reconsider writing plays "largely at the insistence of his old friend Norman-Forbes-Robertson, who was about to take over the management of the Globe Theatre and was therefore in urgent need of plays" (Morley, 1997: 78). Obviously, in addition to a direct mode of expression, the theatre was also a means of income for Wilde. As Hankin also states, Wilde "wanted a great deal of money and he wanted it quickly. [...] And if an artist wants a large income and wants it at once, he generally has to condescend a good deal to get it. Wilde conde- 
scended" (2008: 51). However, as it will be discussed in detail below, it would be wrong to assume that "Wilde the radical" complied with the theatrical conventions of the late nineteenth-century completely. Instead, Wilde adopted a safe stance by observing the conventions of the period first, and then he adapted them according to his own purpose. Wilde acknowledged the fact that to get a license for the staging of his plays it was compulsory to be in accord with the regulations of the Lord Chamberlain (Eltis, 1996: 61). This is the reason why Wilde's plays should be analysed in the light of a comprehensive approach: while they seem to be conventional on the surface, underneath there remains an entirely different interpretation.

Approached by George Alexander, the actor-manager at the St. James's theatre, Wilde was persuaded to write a Society Comedy in 1891 which eventually evolved into Lady Windermere's Fan (Sammells, 2000: 83). During this period the influence of the Norwegian playwright Henrik Ibsen (1928-1906) was widely felt throughout London. Ibsen's play A Doll's House (1879) was performed at the Novelty Theatre in London in 1889, and it ushered in a new age in the history of modern theatre in terms of illustrating the outcry of a domestic wife, Nora Helmer who chooses to go against the established rules of the patriarchal system by leaving her doll's house. The character Nora can be evaluated as an alternative to the overidealised image of the Victorian woman who is expected to be "the angel in the house" as introduced by Coventry Patmore (1823-1896) in his narrative poem (1854) of the same title. As a Victorian writer, Wilde was aware of the seclusion of women from the public sphere. Fuelled by the ideological divisions set between men and women, the Victorian psyche was controlled by the doctrine of "separate spheres" which argued that men belonged to the public sphere while women were associated with the tenets of the private/domestic sphere. Slamming the door and leaving the private sphere behind, the character Nora, therefore, functioned as an inspiring figure who provided a basis for the emergence of characters that started to challenge the divisions between strict binaries. Evidently, Wilde was much influenced by lbsen - mostly because in his plays the Norwegian playwright was portraying a modern vision of life which Wilde wanted to achieve himself. Just like A Doll's House which - as proclaimed by George Bernard Shaw - "'gave Victorian domestic morality its death-blow"' (qtd. in Worth, 1987: 19), Wilde wanted to reflect the Victorian hypocrisy upon itself. In his endeavour 
to realize this end, he undermined the theatrical conventions of the period and made them bend to his purpose:

"Modern" was Wilde's key word, but his technique was to use the old forms made familiar and agreeable to the audience through "fine acting". Besides melodrama, farce and burlesque were the reigning forms in the nineteenth-century theatre. Wilde was very much aware of the possibilities in these forms of modern subversiveness (Worth, 1987: 20).

In this manner, it can be argued that Lady Windermere's Fan demonstrates Wilde's intention to challenge the rigid distinctions constructed between the "divergent" ends - such as the good and the bad, the angelic and the fallen, the sincere and the hypocritical by showcasing the ambivalent points shared by both parties. However, as it has been stated above, Wilde attempts to read against the established agenda of the Victorian mindset not through negating its norms and rules directly - because he needs the Lord Chamberlain's license - but subverting them to be able to find an alternative sphere that can embrace a non-hierarchical reinterpretation of the stereotypical divisions ascribed to Victorian women. Accordingly, in the feminist criticism of the twentieth century it is possible to find the reflections of Wilde's aim to go beyond the strict dualities of the Victorian England. While it is beyond the main scope of this study to apply a postmodern or feminist reading to Lady Windermere's Fan, in order to highlight the importance of the source text's binary-bending implications, it is also significant to make reference to the attempts of the feminist critics to problematize the essentialization of women by the patriarchy. In line with Oscar Wilde's purpose to reflect the constructed status of the strict definitions, especially the "distinction" between the good and the bad woman, Julia Kristeva, too, - without necessarily falling into the trap of stereotypical inscriptions that are likely to strengthen these divisions rather than criticising them - questions the normative and the logocentric aspect of the language as a controlling mechanism. In "The System and the Speaking Subject," Kristeva underlines the symbolic and the semiotic dimensions of language, and she projects the semiotic dimension as an inclusive realm that can unshackle the oppressive dynamics of the former because,

the symbolic aspect is associated with authority, order, fathers, repression, and control [...]. This symbolic facet of language maintains the fiction that the self is fixed and unified [...]. By contrast, the semiotic aspect of discourse is characterised not by logic 
and order, but by "displacement, slippage, condensation," which suggests, again, a much looser, more randomised way of making connections, one which increases the available range of possibilities. (Barry, 1995: 128-29).

However, it should be noted that Kristeva does not call for a total ignorance of the symbolic aspect of the language; she does not celebrate an "ideal" return to the prelapsarian state of the semiotic dimension either. Rather, she maintains that creative mediums, such as art and literature, can help us explore the semiotic dimension of the language and make the remoulding of the strict dualities possible. Hereby, it is possible to argue that instead of upturning the conventions of the Victorian society and criticising them explicitly, Wilde uses literature to explore the ambivalent areas between strict codes and norms. Accordingly, it is functional that in the title of his work, Lady Windermere's Fan, Wilde calls attention to the dynamic and unfixed character of the fan itself - since it can be used in various ways - and he paves the way for the emergence of different interpretations and stances that can allow the reader/audience to discover new ways of overpowering the dualistic agenda of the Victorian patriarchy.

\section{Lady Windermere's Fan}

Lady Windermere's Fan, commonly grouped with A Woman of No Importance (1893), and An Ideal Husband (1893), under the title of "Wilde's Society Comedies," was first produced on 20 February 1892 at St. James Theatre, London and "enjoyed the longest run of any of Wilde's plays: 197 performances" - earning its playwright $£ 7000$ in its first year (Sammells, 2000: 85). After the first performance, however, the play's script underwent a change, and the final version was published in 1893. It is also important to note that Wilde's play "was the first major English stage comedy since The School for Scandal more than a hundred years earlier" (Morley, 1997: 82), and the scene in Act Three, where Lady Windermere and Mrs Erlynne hide behind the curtain, is usually interpreted to be recalling the scene in R. B. Sheridan's (1751-1816) The School for Scandal (1777) where Lady Teazle uses the screen to conceal her identity from her husband.

In four acts with three settings, Lady Windermere's Fan is set in the present-day London and presents a familiar plot for the audience of its time. It is about a crisis in the life of a young wife, Lady Windermere, who, getting suspicious of her husband's illicit love affair, decides to leave her home and her child. However, realizing her mistake just in time, Lady Windermere re- 
turns her home with a more welcoming stance about people. In addition, the play also presents the return of the long-absent mother, Mrs Erlynne, who sacrifices herself for her daughter at the expense of getting further ostracized and distanced from society. In this light, "[t]he plot is that of a sentimental melodrama complete with a moral: the duty of a mother to her child. [...] To soften this stern message the play preaches a lesson on Christian charity. Lady Windermere is made aware of her own fallibility, and is thereby brought to look more kindly on the sins of others" (Eltis, 1996: 56). Nevertheless, in his work, Wilde does not follow the conventional plot line of the sentimental melodramas blindly; instead, he borrows and adapts various materials taken from them and comes up with a personal interpretation of his own.

In the late 1870s and 1880s, "when Wilde was acquiring experience as a theatre goer" (Worth, 1987: 16), the French boulevard theatre was a mainstream, and "[t]he nineteenth-century French theatre had been preoccupied with the 'woman question' from Scribe through Dumas fils to Sardou" (Worth, 1987: 15). The frailty of women and the depravity of the female sex were the main themes that were dealt with in the "well-made plays" of the nineteenth-century playwrights. Wilde was already familiar with the thematic structure of these plays; therefore, it was not unexpected that he would be depicting similar themes related to the problematic position of women in Lady Windermere's Fan:

The tale of a disgraced mother, believed dead, encountering her virtuous daughter was identified as deriving from Odette (1881) by Victorien Sardou. The mother's fear that her former sin will be imitated by her daughter was traced to Révoltée (1889) by Jules Lemaitre. The structure of Wilde's first act was declared to be identical to that of Francillon (1887) by Alexandre Dumas fils, while the forced invitation of the mistress to the wife's private party was found in L'Etrangére (1876) by the same author (Eltis, 1996: 59).

However, as Wilde himself states, "'[t]hose who have seen Lady Windermere's Fan will see that if there is one particular doctrine contained in it, it is that of sheer individualism"' (qtd. in Varty, 1998: 159, emphasis added). In this respect, contrary to the conventional dramatic theme of the fallen woman who repents for her sins and complies with the rules of the society in the end, in his play Wilde portrays a totally contrasting image through Mrs Erlynne who refuses to "perform the rituals of repentance and reform which mark the redemption of the magdalen" (Varty, 1998: 67). Thereby, 
Wilde aptly disguises the true doctrine of his play - which is sheer individualism - behind the surface melodrama of his work.

In Lady Windermere's Fan, subtitled A Play about a Good Woman, Wilde criticizes the tendency of the society to make clear-cut distinctions between the good and the bad. By questioning their "true" meanings and illustrating the points where the binaries can intermingle into one another he draws attention to the fluidity of the self. Thus, it is difficult to decide who the "good" woman of the play is: the puritanical Lady Windermere who reaches a mature understanding of goodness in the end or Mrs Erlynne, the "woman-with-a past", who risks her reputation to be able to save her daughter's marriage? In line with the fluctuating and the dynamic atmosphere of the play, the fan, "the fashion accessory, designed at once for display and concealment, floats free of fixed, authentic signification as it acquires shifting, multiple meanings in the course of the drama" (Sammells, 2000: 85). In Act One, for instance, the fan functions as a birthday gift given by Lord Windermere to his wife - signifying the affectionate bond between the couple; however, in Act Two the fan is transformed into an item of violence that Lady Windermere intends to use to be able to strike the unwelcome guest, Mrs Erlynne, at her birthday ball - who is claimed to be having an affair with Lady Windermere's husband. In Act Three the fan turns out to signify Lady Windermere's infidelity to her husband, as it is discovered in Darlington's rooms, yet soon enough the fan gets associated with Mrs Erlynne's sacrifice for her daughter. Finally, in Act Four Mrs Erlynne wants to return the fan to its owner, but she ends up receiving it as a gift from Lady Windermere. Indicating the interchangeable status of the fan, therefore, it can be asserted that the fan operates as a sign which is defined and redefined in different contexts. Similar to Julia Kristeva's criticism about the stereotypical appropriation of the feminine by a patriarchal order, the ambivalent status of the fan "issues a direct challenge to the domestic normativity it connoted at the beginning" of the play (Sammells, 2000: 87). Within this context, therefore, Lady Windermere's Fan challenges the hierarchical practices constructed between either/or dualities, and it embraces a non-dualistic outlook.

In addition to Wilde's use of the conventional dramatic theme of the fallen woman, he also applies to the popular dramatic form inherited from the French playwrights: "the 'well-made play' with its four-Act structure comprising exposition, complication, obligatory crisis scene and dénoument" (Varty, 1998: 159). Similarly, the props used in Wilde's play - includ- 
ing the private bank book, the letter, and the fan - were familiar to the audience of the period, for they were also used in French boulevard theatre (Sammells, 2000: 88). Yet the individualism of Lady Windermere's Fan lies in the fact that it "simultaneously employs the most familiar motifs and characters, the commonest of devices, and distances itself from them" (Sammells, 2000: 88). In this way, the play achieves to formulate a dynamic tension between the opposites - such as the good and the bad, the emotion and the wit, the physical and the intellectual - and thereby gives rise to various ironies and ambivalences, which add to its thematic richness and complexity.

The fluidity of the meaning ascribed to the fan is also observed in the indeterminate aspects of the main characters in the play. Even though the characters are associated with certain qualities that "seem" to be firm and strict at the beginning, as the events unfold Wilde allows the reader/audience to have a closer look at the changes the characters are going through. To illustrate, in Act One, Lady Windermere is introduced as a figure who is inflexible and idealistic in her puritanical outlook towards life. In her dialogue with Lord Darlington, she describes herself as follows:

Well, I have something of the Puritan in me. I was brought up like that. I am glad of it. My mother died when I was a mere child. I lived always with Lady Julia, my father's elder sister, you know. She was stern to me, but she thought me what the world is forgetting, the difference that there is between what is right and what is wrong. She allowed of no compromise. I allow of none." (Wilde, 1968: 15, emphasis in original).

Lady Windermere's dogmatic stance mainly stems from her leading a sheltered life which causes her to be kept away from the dialogic and multi-dimensional nature of Oscar Wilde's modern interpretation of the "truth" which encompasses the good and the bad, the right and the wrong in the same bowl. Replacing the truth of her mother with the false image of an ideal one who did not run away with her lover, but died years ago, Lady Windermere inadvertently imprisons herself into a fictitious world, and she misses out the complexity of the immediate experience:

LORD DARLINGTON. I think life too complex a thing to be settled by these hard and so fast rules.

LADY WINDERMERE. If we had "these hard and fast rules," we should find life much more simple. 
LORD DARLINGTON. You allow no exception?

LADY WINDERMERE. None! (Wilde, 1968: 17).

Lord Darlington first questions Lady Windermere's blind adherence to the ideals, and then he lays the groundwork for her upcoming attempt to defy the rules of the society by reminding her that she may want a "friend" someday. Hiding his true intentions behind the façade of friendship, however, Lord Darlington plans to have an affair with the lady. According to Shewan, "Darlington thus plays the libertine playing the honnéte homme, an amusing ultra-modern anachronism which counterbalances Lady Windermere's quasi-courtly puritanism" (1982: 138). In this way, Wilde uses Darlington as his mouthpiece for the unorthodox morality, and he attributes him with certain characteristics of the Wildean dandy. Nevertheless, it should be stated that Oscar Wilde did not invent dandyism but added essential elements to it and made it unique. In essence, the theory of dandyism was developed in France by Jules Barbey D'Aurevilly and Charles Baudelaire (Ganz, 1982: 130). Dandyism foregrounds the dandy as an individual who demands absolute freedom and uses his wit to shock and startle the society. Accompanying these characteristics of the dandiacal tradition, the Wildean dandy, however, is distinguished by his/her theory of sensation which gives importance to the process rather than the outcome of the experience, and by his/her exchange of moral values with aestheticism. To illustrate, in relation to the prioritization of the aesthetic standards, Lord Darlington expresses his ideas in the play as follows: "It is absurd to divide people into good and bad. People are either charming or tedious" (Wilde, 1968: 17). Nonetheless, while Darlington incorporates the main elements of the Wildean dandy in himself, paradoxically enough, he also goes against them "by first seeking to influence Lady Windermere and then by subscribing to exactly the values he questions by worshipping her as the embodiment of female virtue" (Eltis, 1996: 90). To put it more precisely, though temporarily successful, Darlington fails both as a dandy and as a romantic lover in the long run (Shewan, 1982: 143) because he can be neither of them. Besides, contrary to the premises of dandyism that are in line with aestheticism which "was a protest against Victorian utility, rationality, and realism" (Eltis, 1996: 6), Darlington "reinforces the simple moral structure of the play [by] presenting an immoral counterpart to Lord Windermere, the upright and protective husband" (Eltis, 1996: 91). Hence, turning out to be a more ambiguous character than he seems to be at first, Darlington adds to the richness and the complexity of the play. 
As for Lady Windermere, who is portrayed as a firm, puritan woman ruled by her own hard and fast rules at the beginning of the play, it is ironic to see that just like Lord Darlington who betrays his own principles, Lady Windermere's idealistic perception of life crumbles away once her jealousy is triggered. As her suspicions - planted by Duchess of Berwick - become justified when she finds out that her husband has been sending money to Mrs Erlynne, Lady Windermere loses her control and goes further enough to vow to attack Mrs Erlynne with her fan if she dares to show up in her birthday ball:

LADY WINDERMERE. [...] Yes, you gave me this fan today; it was your birthday present. If that woman crosses my threshold, I shall strike her across the face with it.

LORD WINDERMERE. Margaret, you couldn't do such a thing.

LADY WINDERMERE. You don't know me! [Moves R.]. (Wilde, 1968: 27).

Here, it is seen that Lord Windermere does not really "know" his wife that motivated by the desire to take revenge on her husband and under the influence of a fit of jealousy she can even leave her home and her child behind. Therefore, Lady Windermere "reveals herself to be both sanctimonious and vindictive" (Miller, 1982: 47), which contradicts with her puritanical vision that has been underlined at the beginning of the play.

Contrary to Lady Windermere, Lord Darlington and Lord Windermere who are introduced directly into the play - as the reader/audience can observe their actions in Act One - Mrs Erlynne does not appear physically, but she is presented as a gossip topic. While the Duchess of Berwick makes sinister comments about Mrs Erlynne's past, "[m]any a woman has a past, but I am told that she has at least a dozen, and that they all fit" (Wilde, 1968: 20), Lord Windermere is more temperate in his observations: "Mrs Erlynne was once honoured, loved, respected. She was well born, she had position she lost everything - threw it away, if you like" (Wilde, 1968: 25). By presenting two different interpretations pertaining to the same person, Wilde, in fact, points to the arbitrariness of making judgements about people which is exemplified through the playwright's portrayal of the ambivalences and inconsistencies inherent in Lady Windermere and Lord Darlington, as analysed so far.

Mrs Erlynne, standing for the "woman with a past", appears in body and flesh at Lady Windermere's birthday celebration in Act Two, where 
Wilde presents a general outlook of the Victorian morals by allowing the reader/audience to have a direct glimpse at her motivations. Secretly blackmailing Lord Windermere to be able to find her way back into the coterie, Mrs Erlynne is also determined to get a marriage proposal from Lord Augustus, who is wealthy enough to secure her a powerful position in the society. In parallel to Mrs Erlynne's so-called strategy, the Duchess of Berwick is on her way to find a suitable husband for her daughter, Agatha whom she keeps "ignorant to ensure her marriageability" and pays utmost importance to control her actions - without leaving her any freedom of choice (Eltis, 1996: 92). In this light, as Eltis further argues, "Lady Agatha is a comic caricature of the innocent young girl, the dutiful young daughter, who utters no words but 'Yes Mamma'" (1996: 84). Here, by juxtaposing the materialist mother figure - as represented through the Duchess of Berwick - against Mrs Erlynne, who "seems" to be selfish and occupied with her own interests, Wilde also prepares the reader/audience to question the dichotomy between reality and appearance. While the Duchess of Berwick does not refrain from objectifying her daughter and continues showcasing herself as an exemplary maternal figure, Mrs Erlynne, realising the farewell note Lady Windermere left for husband, decides to act immediately to be able to defend Lady Windermere's dignity, for she does not want her daughter to commit a grave mistake:

MRS ERLYNNE. Thanks! What can I do? What can I do? I feel a passion awakening within me that I never felt before. What can it mean? The daughter must not be like the mother - that would be terrible. How can I save her? How can I save my child? A moment may ruin life. Who knows that better than I? Windermere must be got out of the house; that is absolutely necessary (Wilde, 1968: 45).

Not conforming to the dictates of the selfish society, Mrs Erlynne rushes to Lord Darlington's flat and protects her daughter at the cost of her own reputation; thus, she "reveals herself capable of generosity, love, and selfsacrifice" (Miller, 1982: 50). On the other hand, Lord Windermere, who presents himself as a protector of his wife, quickly turns out to be the opposite once he sees Lady Windermere's fan in Lord Darlington's rooms: "Speak, sir! Why is my wife's fan here? Answer me! By God! I'll search your rooms, and if my wife's here, l'll - [Moves]" (Wilde, 1968: 57). It is not difficult to guess what the husband's reaction would be if he were to find his wife in the room - he would easily turn his back on her, and this would pave the way for Lady 
Windermere's disreputable association as a "fallen woman" in the eyes of the society. Thereby, it becomes clear that Lord Windermere's main motivation behind hiding the 'true' identity of Mrs Erlynne from his wife is not that he wants to preserve her innocence, but to maintain the respectability of his name.

Just as the way Lady Windermere's puritanical outlook towards life changes, as she finds herself on the threshold of adultery and realizes her susceptibility to sin, Mrs Erlynne "begins with an old-fashioned selfish motive and ends with a radically unselfish one, refraining from revealing herself to her daughter and therefore removing herself from interference in the Windermeres' life" (Varty, 1998: 162). Although she is seen as a "woman with a past", Mrs Erlynne's wit and prudence place her above the normative prescriptions of the Victorian society. Having witnessed the society's hypocritical attitude by first-hand, therefore, Mrs Erlynne is the one who can see through its pretensions:

Lord Windermere must not know of his wife's weakness, or his love for her may die. Lady Windermere must not know of her mother's true identity, or her belief in truth and virtue may die. Mrs Erlynne alone has the breadth and strength of mind to know and accept all. Wilde thus reverses the traditional hierarchy of the fallenwoman play, challenging the moral values and social conventions on which it is based (Eltis, 1996: 58).

As Stokes argues, the originality of Lady Windermere's Fan does not lie in its plot nor in its wit alone: what distinguishes the play from others is "the way in which wit is seen as a part of the moral problem-an interest that links Wilde with the Restoration playwrights" (1978: 37). In this light, paradoxically enough, only through the witty deceit and the role-play, can the hypocrisy of the society be turned against itself. Mrs Erlynne, by appearing to be a "bad" woman, assures the innocence of her daughter; similarly, by making Lord Augustus believe that she is innocent - that is a "good" woman - Mrs Erlynne also guides him into marriage in the end. In a similar vein, despite their sophistication and intelligence, the group of gentlemen in Lord Darlington's room are described to be lacking foresight because they cannot see beyond either/or dualities. Instead, they choose to sharpen the stereotypical divisions between the opposing ends:

LORD AUGUSTUS. You want to make her [Mrs Erlynne] out a wicked woman. She is not! 
CECIL GRAHAM. Oh! Wicked woman bother one. Good woman bore one. That is the only difference between them.

LORD AUGUSTUS [puffing a cigar]. Mrs Erlynne has a future before her.

DUMBY. Mrs Erlynne has a past before her.

LORD AUGUSTUS. I prefer women with a past. They're always so damned amusing to talk to (Wilde, 1968: 52).

Through these scandalmongers and their reductionist view concerning women, who are pushed to the margins of the society, Wilde raises questions about the conventional delineation of the good and the bad. Moreover, Wilde also shows how the binaries can meet on the same ground and can offer an alternative interpretation - as Mrs Erlynne proves herself to be an amalgamation of both. Even though Lady Windermere's Fan carries the characteristics of the sentimental drama of society of manners, beneath the surface it hints at a hidden layer of meaning that surpasses all the conventional definitions that have been celebrated so far. Through Mrs Erlynne, Wilde intends to improve the critical gaze of his reader/audience, for he does not adhere to the hypocritical moral standards of the Victorian era. As Mrs Erlynne also highlights the paradoxical importance placed upon "manners before morals" in her dialogue with Lady Windermere (Wilde, 1968: 62), it is seen that Victorian 'ideals' have long been emptied inside. Despite having undergone a change, however, Lady Windermere lacks the unifying vision of her mother because she is still sticking to the "ideal" that she has created in her mind. Hence, Lady Windermere is not ready to accept the reality in its "pure" form, yet:

MRS ERLYNNE. You are devoted to your mother's memory, Lady Windermere, your husband tells me.

LADY WINDERMERE. We all have ideals in life. At least we all should have. Mine is my mother.

MRS ERLYNNE. Ideals are dangerous things. Realities are better. They wound, but they're better.

LADY WINDERMERE [shaking her head]. If I lost my ideals, I should lose everything (Wilde, 1968: 66).

Therefore, it is ironic that Lady Windermere interprets Mrs Erlynne as a "good woman" at the end of the play (Wilde, 1968: 70). In this manner Eltis argues that "were she [Lady Windermere] to know Mrs Erlynne's true iden- 
tity she would undoubtedly consider her anything but 'good,' while the labelling of women as 'good' or otherwise is precisely what Mrs Erlynne herself had rejected" (1996: 82). Thereby, Mrs Erlynne challenges the hypocritical premises of the society, first by rejecting to comply with the 'idealistic' maternal role ascribed to her, and then by accepting Lord Augustus' marriage proposal - on the condition that they live out of England. Considering the fact that Wilde himself spent the final years of his life in France, Mrs Erlynne's decision to leave England can also be interpreted as Wilde's ultimate criticism of the Victorian society in the late 1890s. However, unlike Henrik Ibsen who explicitly exposes the double standards and directs a harsh criticism against the normative gender roles ascribed to women, Oscar Wilde remoulds and reinterprets the traditional norms from a much more humorous perspective, and, in this way, he manages to make his reader/audience to use their mind and heart to be able to draw their own conclusions.

\section{Conclusion}

In Lady Windermere's Fan Wilde appropriates and reshapes the conventions of the popular nineteenth-century dramas - such as the sentimental melodrama and the French boulevard theatre - and, in this way, he subtly criticizes the morals of the Victorian society that he portrays in his play. He points to the hidden layer of meaning that stays behind the surface and, thus, earns his work its individual character which defies the hypocritical Victorian mindset and the conventional social morality of his period. Structuring his play upon the tension situated between the stereotypical and normative prescriptions pertaining to gender roles in the broader, and juxtaposing Mrs Erlynne and her daughter Lady Windermere as reflections of each other in the narrower perspective, Wilde intends to illustrate the ambivalent and the interchangeable status of the meaning-making practices in the Victorian society. Epitomizing the grey areas between a puritanical lady who comes to the verge of leaving her husband out of a fit of jealousy and her so-called "disreputable" mother who is "good" and brave enough to guarantee the dignity of her own daughter at the expense of risking her own reputation, Lady Windermere's Fan reveals the hypocrisy as well as the inconsistent nature about the artificial divisions between good and bad, innocent and guilty, faithful and corrupt, and thereby it also lights the way for the modern representation of the "reality" on the English stage without necessarily presenting an unrealistic and sentimental evaluation of the Victorian society. 


\section{References}

Barry, Peter (1995). Beginning Theory: An Introduction to Literary and Cultural Theory. Manchester: Manchester University Press.

Ellmann, Richard (1969). "Introduction." Oscar Wilde: A Collection of Critical Essays. Ed. Richard Ellmann. New Jersey: Prentice-Hall, 1-8.

Eltis, Sos (1996). Revising Wilde: Society and Subversion in the Plays of Oscar Wilde. Oxford: Clarendon.

Ganz, Arthur (1982). "The Divided Self in the Society Comedies of Oscar Wilde (1960)." Wilde: Comedies. Ed. William Tydeman. London: The Macmillan, 126-134.

Hankin, St. John (2008). "St. John Hankin: The Collected Plays of Oscar Wilde (1908)". Oscar Wilde. Ed. Harold Bloom. New York: Infobase Publishing, 50-52.

Miller, Robert Keith (1982). Oscar Wilde. New York: Frederick Ungar.

Morley, Sheridan (1997). Oscar Wilde. London: Pavilion.

Raby, Peter (1988). "Plays: the Social Comedies". Oscar Wilde. Cambridge: Cambridge University, 81-100.

Raby, Peter (1997). "Wilde's Comedies of Society". The Cambridge Companion to Oscar Wilde. Ed. Peter Raby. Cambridge: Cambridge University, 143-160.

Sammells, Neil (2000). Wilde Style: The Plays and Prose of Oscar Wilde. Essex: Longman.

Shewan, Rodney (1982). "Lady Windermere's Fan: The Critic as Dramatist (1977)". Wilde: Comedies. Ed. William Tydeman. London: The Macmillan, 134-145.

Stokes, John (1978). Oscar Wilde. London: Longman.

Varty, Anne (1998). A Preface to Oscar Wilde. New York: Longman.

Wilde, Oscar (1968). Lady Windermere's Fan: A Play about a Good Woman. London: Penguin.

Worth, Katharine (1987). Oscar Wilde. London: MacMillan Education. 
Kültür Araştırmaları Dergisi, 10 (2021)

The following statements are made in the framework of "COPE-Code of Conduct and Best Practices Guidelines for Journal Editors":

Ethics Committee Approval: Ethics committee approval is not required for this study.

Declaration of Conflicting Interests: The author has no potential conflict of interest regarding research, authorship or publication of this article. 